\title{
ANTINUCLEAR FACTORS IN RHEUMATOID ARTHRITIS \\ INCREASING ORGAN-NON-SPECIFICITY WITH INCREASING REACTIVITY OF RHEUMATOID FACTOR WITH HETEROLOGOUS GAMMA GLOBULIN*
}

\author{
BY \\ P. ELLING \\ From the Auto-immune Laboratory, Statens Seruminstitut, Copenhagen, Denmark
}

McCormick and Day (1963) reported that rheumatoid factors and 7S ANF co-existing in the same sera may form high molecular weight complexes, and absorption studies have brought forward evidence of an interaction between ANF and rheumatoid factors when present in the same serum (Holborow and Johnson, 1965). However, ANF in rheumatoid arthritis have mostly been found in low frequency and chiefly in the 19S gamma globulin fraction (Weir and Holborow, 1962; Baum and Ziff, 1962); as emphasized by Baum and Ziff (1962) such gamma globulin cannot be the 7S substrate required for rheumatoid factors.

It has recently been shown, however, that a high proportion of sera and synovial fluids from patients with definite rheumatoid arthritis may contain IgG ANF, which reacts exclusively with a DNAse sensitive antigen localized in nuclei of (polymorphonuclear) granulocytes (Elling, 1967; Elling, Graudal, and Faber, 1967, 1968). The limited nuclear reactivity of this antinuclear antibody may suggest that its production is caused by an immunization with nuclear material derived from polymorphs rather than from bacteria or virus. The presence of granulocyte-specific ANF in synovial fluids and not in corresponding sera in some cases may also suggest that the nuclear material is derived from polymorphs involved in the arthritic inflammation (Elling and others, 1968).

In clinical material, highly controversial results have appeared concerning the relationship between rheumatoid factors and ANF. Since these variations may be caused by the existence of ANF with limited nuclear reactivity, the present investigation into the relationship between these factors was performed with special emphasis on the correlation between ANF with monospecificities or multispecificities and the two main groups of rheumatoid

*This work was supported by the Daell Foundation and Konsul Zhrenfried Owesén and Hustru's Foundation. factors, i.e. rheumatoid factors reactive with auto- . logous (isologous) gamma globulin or heterologous gamma globulin.

\section{Material}

Sera from 137 cases of adult rheumatoid arthritis were $\bar{D}$ selected from two sources:

(1) From in-patients in the King Christian $X \underset{\mathbb{D}}{\vec{D}}$ Arthritis Sanatorium, Gråsten, and in the Rheumatism Research Unit, Århus Kommunehospital.

(2) From sera received for routine examination of ANF in this laboratory.

The sera were selected according to the followin criteria:

(1) All patients should have definite or classic rheumatoid arthritis. The patients from the arthritic clinics all satisfied the criteria of the American Rheumatism Asso- $\stackrel{\circ}{\circ}$ ciation (1959). The remaining sera were derived from $\cong$ patients with a diagnosis established during treatment in $\overrightarrow{\vec{B}}$ general hospitals.

(2) All sera should show a positive ANF reaction when granulocytes were used as nuclear antigen in the immunofluorescent antibody technique. Only sera showing a homogenous nuclear staining pattern were included.

\section{Methods}

A two-layer immunofluorescent antibody technique was used for the determination of ANF, as has been described previously (Elling, 1967). In this study, $\frac{O}{工}$ human blood smears which were frozen and thawed im- $D$ mediately after preparation were used as nuclear source for granulocytes and lymphocytes. Besides these, $4 \mu \tilde{N}$ cryostat sections of human thyroid tissue, gastric mucosa, or kidney tissue, and rat liver were employed as nuclear $N$ antigens. The antiserum-a rabbit antihuman gamma N globulin which immunoelectrophoretically showed pre- $\omega$ cipitating lines against human gamma globulin onlywas conjugated with fluorescein-isothiocyanate $(25 \mathrm{mg} . / \mathrm{g}$. protein) as previously described (Elling, 1967).

Rheumatoid factors reactive with heterologous gamma $\stackrel{?}{+}$ globulin were. determined by agglutination of sheep $\square$ cells sensitized with rabbit amboceptor, as has been 0 
described in detail (Norup, 1967). Sera were inactivated and absorbed with packed sheep cells at room temperature before the determination. For sensitization of the sheep cells, one half of the minimum agglutinating dose was used, employing a 2 per cent. solution of sheep cells washed in saline. With this technique the WHO international reference preparation of rheumatoid arthritis serum was repeatedly positive at a titre of $1: 1280$.

Rheumatoid factors reactive with isologous gamma globulin were determined by the use of latex particles sensitized with Cohn fraction II of human serum (FII latex test, Hyland reagent).

\section{Results}

Fig. 1 shows the results of the investigation of sera for the nuclear specificity of ANF and the incidence and titres of the two rheumatoid factors. The 137 ANF-positive sera could be divided according to the nuclear specificity into two main groups: one consisting of sixty sera which reacted exclusively with nuclei of polymorphs (granulocyte-specific ANF) within the limits of the organ nuclei employed, and the second consisting of 77 sera which reacted with nuclei of polymorphs as well as with one or more of the other nuclei included (organ-nonspecific ANF).

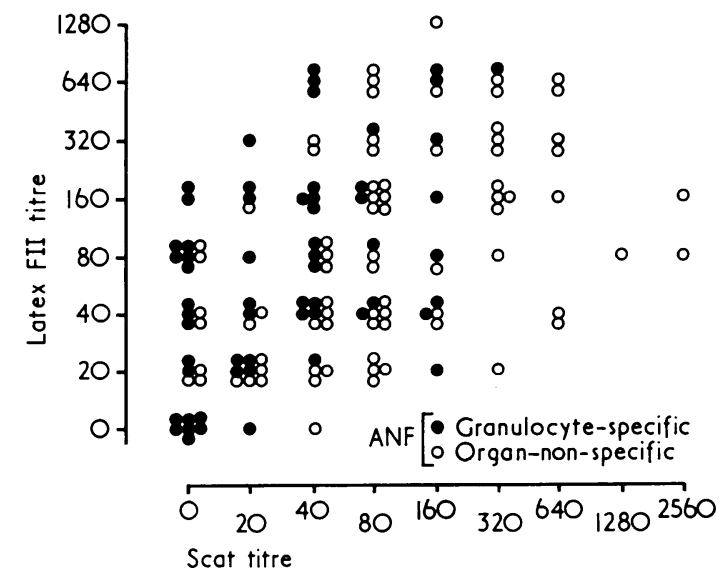

Fig. 1.-Relationship between granulocyte-specific and organ-nonspecific ANF and titre of rheumatoid factors reactive with isologous gamma globulin (positive FII latex test) and heterologous gamma globulin (positive SCAT test) in 137 sera from adult patients with definite or classic rheumatoid arthritis.

The incidence of rheumatoid factors reactive with isologous gamma globulin (positive FII latex test) at a titre of 20 or greater was 94 per cent. (128 out of 137 sera). The rheumatoid factor reactive with heterologous gamma globulin (positive SCAT test) at a titre of 20 or greater was found in 72 per cent. of the sera (111 out of 137 sera).

Fig. 2 shows the percentage of the ANF-positive sera which for a given titre of the two rheumatoid

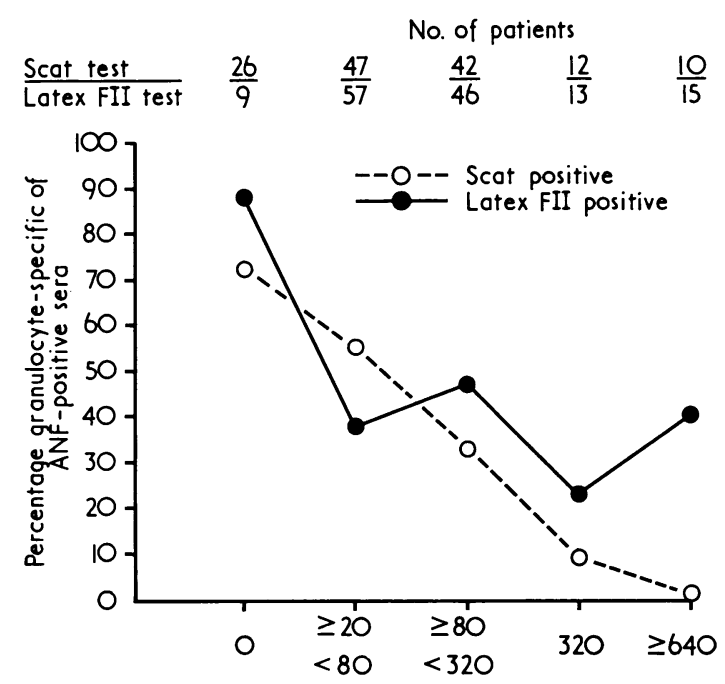

Scat and latex FII titre

Fig. 2.-Percentage of ANF-positive sera which for a given titre of the two rheumatoid factors contain granulocyte-specific ANF.

factors contain granulocyte-specific ANF. The Figure shows a linear decrease in the percentage of sera which contain granulocyte-specific ANF when the titres of the two rheumatoid factors increase; similarly the percentage of sera containing organnon-specific ANF increases linearly with increasing titres of both rheumatoid factors. Thus, in sera showing a negative FII latex and SCAT reaction, granulocyte-specific ANF make up 88 per cent. and 73 per cent. respectively of the ANF-positive sera, while the incidence of this ANF in sera which show a positive reaction for both rheumatoid factors decreases considerably. This decrease is especially pronounced with increasing SCAT titres, where a linear fall to zero is found, while the decrease of the incidence of granulocyte-specific ANF with increasing titres of the latex factor is not so conspicuous. After an initial fall in the incidence of granulocytespecific ANF, from 88 per cent. positive in latexnegative sera to 40 per cent. positive in latexpositive sera of low titres, the incidence of granulocyte-specific ANF remains rather constant despite higher titres of the latex FII factor. This finding suggests that the decrease in the incidence of granulocyte-specific ANF in sera from patients with rheumatoid arthritis is more closely correlated to the production of rheumatoid factors reactive with heterologous gammaglobulin than to the latex FII rheumatoid factor. Similarly, while a linear increase in the percentage of organ-non-specific ANF with increasing SCAT titres is evident with increasing titres of the latex FII factor, the percentage of sera containing organ-non-specific ANF shows only slight variations. 
This close relationship between the nuclear specificity of ANF and rheumatoid factors with specificity for either isologous or heterologous gamma globulin may also be seen if the ratio between the titres of the FII latex and the SCAT factor is plotted in a logarithmic form against the percentage of sera which contain granulocyte-specific or organnon-specific ANF (Fig. 3). Thus, if the $\log _{10}$ ratio of the titres of the two rheumatoid factors is positive (FII latex titre > SCAT titre), the percentage of sera containing organ-non-specific ANF is low and the percentage of sera containing granulocytespecific ANF is high. On the contrary, when the $\log _{10}$ ratio becomes negative (SCAT titre < latex FII titre), the percentage of sera which contain granulocyte-specific ANF decreases to zero, while a steep increase in the incidence of organ-nonspecific ANF is evident.

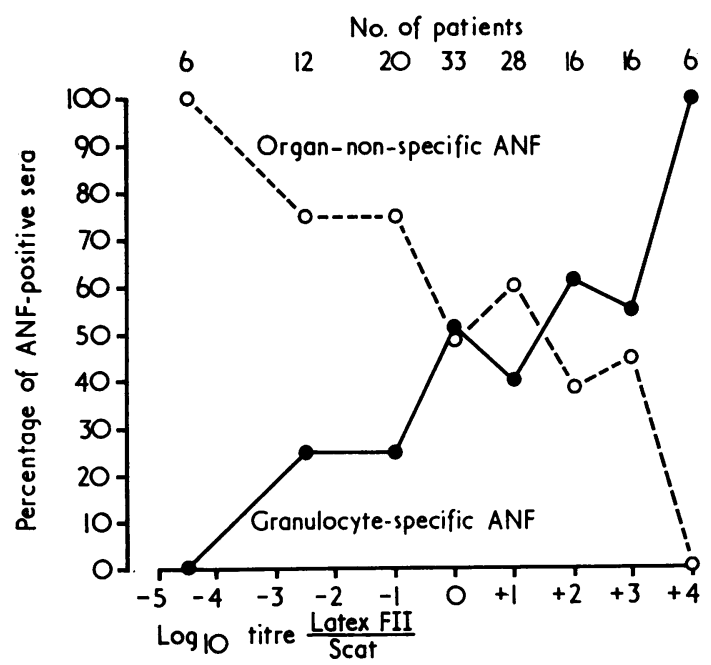

Fig. 3.-Relationship of $\log _{10}$ ratios between the titres of the FII latex and the SCAT rheumatoid factor and the nuclear specificity of ANF.

In 82 cases in which valid data on the duration of the disease were available, these data have been compared with the results of the serological test. Fig. 4 shows that granulocyte-specific ANF is found in a slightly higher frequency in sera from patients with short duration of disease than in sera from patients with longer duration of disease; however, this difference does not reach a significant level. In contrast, sera from patients with long duration of disease (more than 5 years) contain significantly $(P<0.01)$ more frequently organ-non-specific ANF than do sera from patients with short duration. However, the results shown in Fig. 5 (opposite) may also indicate that the specificity of ANF is not a

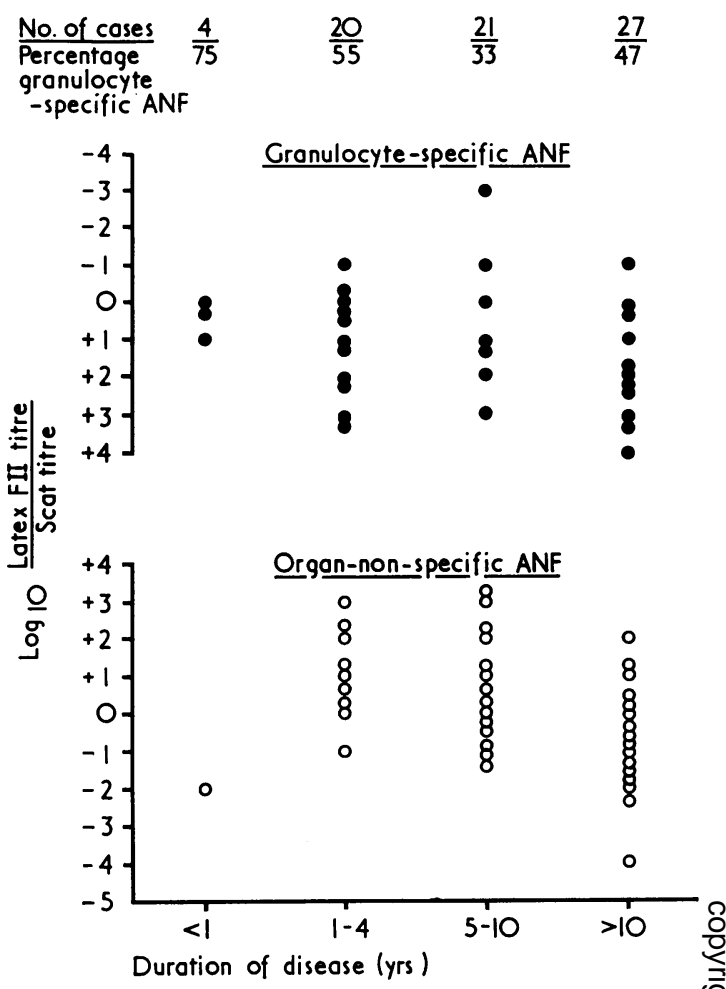

Fig. 4.-Nuclear specificity of ANF and $\log _{10}$ ratio of titres of rheumatoid factors reactive with isologous and heterologous gamma globulin, compared with duration of disease in 82 patients with rheumatoid

function of the duration of disease, but correlated more closely to the specificity of rheumatoid factors. Thus, irrespective of the duration of disease, sera containing granulocyte-specific ANF show only little change in the specificity of rheumatoid factors; on the contrary, in sera containing organ-nonspecific ANF, the $\log _{10}$ ratio of the titres of the two rheumatoid factors is positive only in sera from patients with short duration of disease (indicating a high latex FII titre and a low SCAT titre), while in sera from patients with longer duration of disease the $\log _{10}$ ratio between the titres of the rheumatoid factors becomes increasingly negative, indicating higher titres of the SCAT rheumatoid factor.

\section{Discussion}

In the present report rheumatoid factors reactive with human gamma globulin (positive FII latex reaction) were frequently found in sera which also contained granulocyte-specific and organ-non-specific ANF, but the essential result was the finding of a 


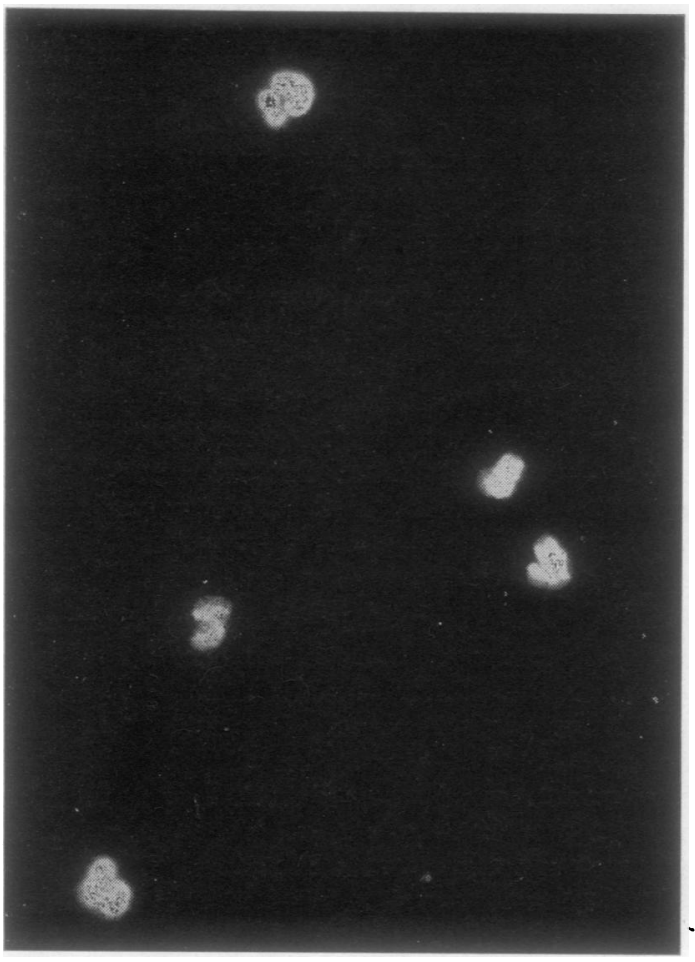

Fig. 5(a).-Granulocyte-spes:fic ANF: Human blood smears pretreated with a serum containing granulocyte-specific ANF and then incubated with FICT-labelled rabbit ant.human gamma globulin. Staining of five granulocytes, but no staining of two lymphocytes (compare Fig. $5(b)$ ).

qualitative change in the specificity of ANF in relation to the occurrence of rheumatoid factors reactive with heterologous gamma globulin (positive SCAT test). That is to say, granulocyte-specific ANF were more frequently found in sera which showed no reaction or only low titred reactions with rabbit gamma globulin, whereas organ-non-specific ANF were chiefly found in sera which contained rheumatoid factors reactive with rabbit gamma globulin.

The data obtained indicate that the occurrence of organ-non-specific ANF in contrast to the occurrence of granulocyte-specific ANF might be a late manifestation of the disease. Though the incidence of the two ANF shows no significant difference in the early stage of the disease, a significantly higher incidence of organ-non-specific ANF was found in sera from patients with a duration of disease of 5 years or more. This may indicate a development in the specificity of ANF in rheumatoid arthritis with the production of granulocyte-specific ANF and later of organ-non-specific ANF. Such a pattern of development may be found in the NZB strain of mice which develop ANF spontaneously (Elling

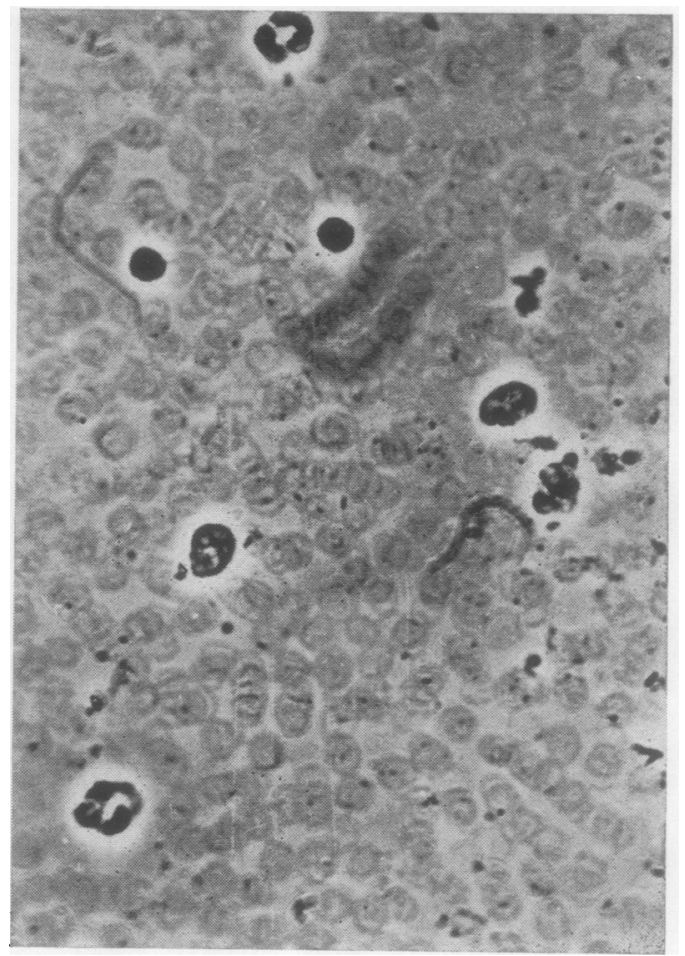

Fig. $5(b)$.- Phase contrast photomicrograph of same field as in Fig. 5(a).

and Hijmans, 1968) and in the Swiss strain of mice which may develop ANF if thymectomized at birth (Thivolet, Monier, Ruel, and Richard, 1967).

However, the present results may also suggest that the specificity of ANF in rheumatoid arthritis is not determined solely by the duration of the disease. From investigations of clinical material (e.g. Sievers, 1965) it is evident that the development of rheumatoid factors reactive with heterologous gamma globulin is a late manifestation in rheumatoid arthritis and represents an increased rate of clinical and roentgenological progression as compared with the condition of patients who are negative for this rheumatoid factor. It is therefore of some importance to notice that, in the present report, only patients who developed organ-nonspecific ANF produced rheumatoid factors reactive with heterologous gamma globulin, and that the production of organ-non-specific ANF apparently preceded the occurrence of rheumatoid factors reactive with heterologous gamma globulin. Thus, according to the results of the serological test, the patients in the present report may be divided into two groups (compare Fig. 4): 
(1) Irrespective of the duration of the disease, this group shows a positive granulocyte-specific ANF reaction and a positive latex FII reaction, but negative or low titred reactions in the SCAT test.

(2) The second group shows a positive organnon-specific ANF reaction; only the patients with disease of short duration show lower titres in the SCAT reaction than in the FII latex test, whereas patients with disease of longer duration and organnon-specific ANF show higher titres of the rheumatoid factors reactive with rabbit gamma globulin.

This relationship may thus indicate-though indirectly-a correlation between the nuclear specificity and the severity of the disease.

Controversial reports have dealt with the specificity of rheumatoid factors reactive with rabbit gamma globulin and the biological significance of the appearance of rheumatoid factors with different specificity. It has been held that the change in the specificity of rheumatoid factors, from being primarily reactive with human gamma globulin to reacting also with heterologous gamma globulin, is caused mainly by an increasing cross-reactivity of rheumatoid factors with antigens closely related to the homologous antigens (Vaughan, 1956; Vaughan, Ellis, and Marshall, 1958; Butler, Gleich, and Vaughan, 1962; Aho and Simons, 1963; Butler and Vaughan, 1965). Several authors, however, have found that rheumatoid factors primarily may possess specificity not only for human gamma globulin but also for rabbit gamma globulin (Lospalluto and Ziff, 1959; Heimer, Levin, and Rudd, 1963; Milgrom, Witebsky, Goldstein, and Loza, 1962; Williams and Kunkel, 1963a; Milgrom and Tönder, 1965; Tönder and Natvig, 1966). Judging from these various studies, it is conceivable that the degree of alteration of the human gamma globulin, i.e. by its interaction with an antigen (Abruzzo and Christian, 1961; Aho and Wager, 1961; Williams and Kunkel, 1962; Aho, Konttinen, Rajasalmi, and Wager, 1962; Williams and Kunkel, 1963b; Christian, 1963), plays a major role in determining the specificity of rheumatoid factors. As has been emphasized by Milgrom and Tönder (1965), variation in the degree of denaturation of the patient's own gamma globulin may expose different hidden antigenic determinants resulting in the appearance of rheumatoid factors with different specificities. The relationship found in the present report between the specificity of ANF and the specificity of rheumatoid factors is in accordance with such an opinion of the development of rheumatoid factors. Thus the dominance of rheumatoid factors reactive with human gamma globulin in sera which contain only granulocyte-specific ANF may suggest that this ANF is produced through a stimulus which is less intense than that required for the production of organ-non-specific ANF and the rheumatoid factors which react with heterologous gamma globulin. It is conceivable that the term "organ-non-specific ANF" embraces a heterogeneous group of antibodies. Absorption studies have revealed the presence of both granulocyte and lymphocytespecific ANF besides the existence of cross-reacting ANF in such sera (Elling, 1966). Since most antibodies show increasing non-specificity with longer and stronger immunization (Cohen and Porter, 1964), it may be assumed that the occurrence of organ-non-specific ANF represents a more vigorous immunization than the stimulation required for the production of granulocyte-specific ANF.

It must be emphasized, however, that the present report demonstrates a statistical correlation only between the specificity of ANF and the specificity of rheumatoid factors, and does not justify any conclusion about the possible aetiological relationship between ANF and rheumatoid factors. The simultaneous development of the specificities of these factors probably reflects the degree of immunization; the occurrence of these various ANF and rheumatoid factors may consequently be indepen dent, though parallel, events in patients with rheumatoid arthritis.

\section{Summary}

Sera were selected from 137 patients with definite rheumatoid arthritis who all showed a positive antinuclear factor reaction when granulocytes were used as antigen in the immunofluorescent antibody technique. These sera were then investigated for the nuclear specificity of the antinuclear factors and the specificity of the rheumatoid factors. The 137 sera could accordingly be divided into two main groups: sixty which reacted exclusively with nuclei of polymorphonuclear granulocytes, and 77 which reacted with a homogeneous staining pattern with other isologous or heterologous nuclei (organ-nonspecific ANF). The incidence and titres of rheumatoid factors reactive with human (isologous) gamma globulin and of those reactive with heterologous gamma globulin were then determined in the two groups of patients.

The results show an almost linear decrease in the percentage of sera containing granulocyte-specific ANF with increasing titres of the rheumatoid factors reactive with heterologous gamma globulin, and a simultaneous linear increase in the incidence of organ-non-specific ANF with an increase in the 
titre of this rheumatoid factor. The change in the specificity of ANF with increasing titres of rheumatoid factors reactive with human gamma globulin was not so conspicuous. After an initial fall in the percentage of sera containing granulocyte-specific ANF after the development of rheumatoid factors reactive with human gamma globulin in low titres, the incidence of granulocyte-specific and organ-nonspecific ANF remained constant in spite of increasing titres of the rheumatoid factors.

In 82 cases in which information on the duration of disease were available, this was compared with the results of the serological test. The organ-nonspecific ANF was found significantly more frequently than granulocyte-specific ANF in sera from patients with disease lasting for 5 years or more, but the difference was not significant in sera from patients with shorter duration of disease.

Irrespective of the duration of disease, sera containing only granulocyte-specific ANF showed little change in specificity of rheumatoid factors, but sera containing organ-non-specific ANF from patients with longer duration of disease showed higher titres of rheumatoid factors reactive with heterologous gamma globulin than those from patients with shorter duration of disease.

The results indicate that the specificity of ANF and that of rheumatoid factors in rheumatoid arthritis are closely correlated. It also appears that the specificity of ANF is not determined only by the duration but also by the severity of the disease.

\section{REFERENCES}

Abruzzo, J. L., and Christian, C. L. (1961). J. exp. Med., 114, 791 (The induction of a rheumatoid factor-like substances in rabbits).

Aho, K., Konttinen, A., Rajasalmi, M., and Wager, O. (1962). Acta path. microbiol. scand., 56, 478 (Transient appearance of the rheumatoid factor in connection with prophylactic vaccinations).

— and Simons, K. (1963). Arthr. and Rheum., 6, 676 (Studies of the antibody nature of the rheumatoid factor).

- and Wager, O. (1961). Ann. Med. exp. Fenn., 39, 79 (Production of "anti-antibodies" in rabbits).

American Rheumatism Association (1959). J. Amer. med. Ass., 171, 1205 (Primer on the rheumatic diseases. Part I).

Baum, J., and Ziff, M. (1962). Arthr. and Rheum., 5, 636 (7S and macroglobulin antinuclear fluorescence factors in systemic lupus erythematosus and rheumatoid arthritis).

Butler, V. P., Gleich, G. J., and Vaughan, J. H. (1962). Ibid., 5, 104 (An immunological basis for the cross-reactivity of rheumatoid factor with animal gamma-globulins).

and Vaughan, J. H. (1965). Immunology, 8, 144 (The reaction of rheumatoid factor with animal gamma-globulins: quantitative considerations).

Christian, C. L. (1963). J. exp. Med., 118, 827 (Rheumatoid factor properties of hyperimmune rabbit sera).

Cohen, S., and Porter, R. R. (1964). Advanc. Immunol., 4, 287 (Structure and biological activities of immunoglobulins).

Elling, P. (1966). Acta path. microbiol. scand., 68, 281 (Reaction of antinuclear factors with polymorphonuclear leucocytes. I. Absorption studies).

(1967). Acta rheum. scand., 13, 101 (On the incidence of antinuclear factors in rheumatoid arthritis).

—, Graudal, H., and Faber, V. (1967). Acta med. scand., 182, 707 (Organ-specific and organ-nonspecific auto-antibodies in rheumatoid arthritis).

,,,$---(1968)$. Ann. rheum. Dis., 27, 225 (Granulocyte-specific ANF and other ANF in sera and synovial fluids from patients with rheumatoid arthritis).

— and Hijmans, W. (1968). In preparation (On the organ-specificity of ANF in the NZB strain of mice).

Heimer, R., Levin, F. M., and Rudd, E. (1963). Amer. J. Med., 35, 175 (Globulins resembling rheumatoid factor in serum of the aged).

Holborow, E. J., and Johnson, G. D. (1965). Ann. N.Y. Acad. Sci., 124, 833 (The nature of antinuclear immunoglobulins).

Lospalluto, J., and Ziff, M. (1959). J. exp. Med., 110, 169 (Chromatographic studies of the rheumatoid factor).

McCormick, J. N., and Day, J. (1963). Lancet, 2, 554 (The association of rheumatoid factor with antinuclear factor activity). 
Milgrom, F., and Tönder, O. (1965). Arthr. and Rheum., 8, 203 (Multiplicity of rheumatoid factor). -, Witebsky, E., Goldstein, R., and Loza, U. (1962). J. Amer. med. Ass., 181, 476 (Studies on the rheumatoid and related serum factors. 2. Relation of anti-human and anti-rabbit gamma globulin factors in rheumatoid arthritis serums).

Norup, G. (1967). Acta path. microbiol. scand., 70, 405 (Complement-fixing liver antibodies. 3.).

Sievers, K. (1965). Thesis. Acta rheum. scand., Suppl. 9 (The rheumatoid factor in definite rheumatoid arthritis).

Thivolet, J., Monier, J. C., Ruel, J. P., and Richard, M. H. (1967). Nature (Lond.), 214, 1134 (Antinuclear autoantibodies in Swiss mice thymectomized at birth).

Tönder, O., and Natvig, J. B. (1966). Acta path. microbiol. scand., 68, 108 (Detection of antigamma-globulin factors in human sera by simple screening methods).

Vaughan, J. H. (1956). J. Immunol., 77, 181 (Behavior of the rheumatoid arthritis agglutinating factor with immune precipitates).

—, Ellis, P. J., and Marshall, H. (1958). Ibid., 81, 261 (Quantitative considerations of the rheumatoid factor).

Weir, D. M., and Holborow, E. J. (1962). Ann. rheum. Dis., 21, 40 (Serum antinuclear factor).

Williams, R. C., and Kunkel, H. G. (1962). J. clin. Invest., 41, 666 (Rheumatoid factor, complement and conglutinin aberrations in patients with subacute bacterial endocarditis).

—- _ (1963a). Arthr. and Rheum., 6, 665 (Separation of rheumatoid factors of different specificities using columns conjugated with gamma-globulin).

,- (1963b). Proc. Soc. exp. Biol. (N.Y.), 112, 554 (Antibodies to rabbit gamma-globulin after immunizing with various preparations of autologous gamma-globulin).

Les facteurs antinucléaires dans la polyarthrite rhumatoïde. La non-spécifité de l'organe qui augmente avec la réactivité du facteur rhumatoíde avec la gammaglobuline hétérologue

\section{RÉSUMÉ}

On choisit les sérums de 137 patients atteints de polyarthrite rhumatoïde "definie" et accusant la présence du facteur antinucléaire démontrée par la méthode d'immunofluorescence avec emploi des granulocytes comme antigène. On rechercha ensuite dans ces sérums la spécificité nucléaire des facteurs antinucléaires et la spécificité des facteurs rhumatoïdes. On put ainsi diviser les 137 sérums en deux groupes principaux: 60 qui réagissaient exclusivement avec les noyaux des granulocytes polymorphonucléaires et 77 qui réagissaient par une coloration homogène avec d'autres noyaux, isologues ou hétérologues (facteur antinucléaire non-spécifique de l'organe). Ensuite on détermina dans les deux groupes des malades l'incidence et les titres des facteurs rhumatoïdes réagissant avec la gamma-globuline humaine (isologue) et de ceux réagissant avec la gamma-globuline hétérologue.

Les résultats montrent une diminution presque linéaire du pourcentage des sérums contenant le facteur antinucléaire spécifique du granulocyte parallèle à l'augmentation des titres des facteurs rhumatoildes réagissant avec la gamma-globuline hétérologue, et en même temps, une augmentation linéaire de l'incidence du facteur antinucléaire non-spécifique parallèle à l'augmentation du titre de ce facteur rhumatoïde. L'altération de la spécificité du facteur antinucléaire par rapport à l'augmentation des titres des facteurs rhumatoïdes réagissant avec la gamma-globuline humaine n'est pas si manifeste. Après une chute initiale du pourcentage des sérums contenant le facteur antinucléaire spécifique du granulocyte quí suit le développement des facteurs rhumatoïdes réagissant aux titres bas avec la gamma-globuline humaine, l'incidence des
Los factores antinucleares en la poliartritis reumatoide. La non-especifidad del organo que aumenta con la reactividad del factor reumatoide con la gammaglobulinao heteróloga

\section{SUMARIO}

Se escogieron sueros de 137 pacientes con poliartritis reumatoide "definida" que evidenciaron factores antinucleares por el método de inmunofluorescencia con granulocitos como antigeno. En estos sueros se buscaron luego la especifidad nuclear de los factores antinucleares y la especifidad de los factores reumatoides. De este modo los 137 sueros se pudieron repartir entre dos grupos principales: 60 reaccionando exclusivamente con los núcleos de los granulocitos polimorfonucleares y 77 dando una coloracion homogénea en reacción con otros núcleos, isólogos o heterólogos (factor antinuclear no específico del órgano). En seguida se determinaron en ambos grupos la incidencia y los títulos de los factores reumatoides reaccionando con la gammaglobulina humana (isóloga) y de los reaccionando con la gammaglobulina heteróloga.

Los resultados muestran una disminución casi linear de la proporción de los sueros conteniendo el factor antinuclear específico del granulocito siguiendo el aumento de los títulos de los factores reumatoides que reaccionan con la gammaglobulina heteróloga y, al mismo tiempo, una aumentación linear de la incidencia del factor antinuclear no específico que sigue la aumentación del título de este factor reumatoide. La alteración de la especifidad del factor antinuclear en relación con la aumentación de los títulos de los factores reumatoides reaccionando con la gammaglobulina humana es menos aparente. Después de la caida inicial de la proporción de los sueros conteniendo el factor antinuclear específico del granulocito que sigue el desarrollo de los factores reumatoides con títulos bajos de su reacción con la gammaglobulina humana, la incidencia de los factores antinucleares específicos del granulocito y no 
facteurs antinucléaires spécifiques du granulocyte et non-spécifiques de l'organe demeurait constante malgré une augmentation des titres des facteurs rhumatoïdes.

Dans 82 cas la durée de la maladie fut connue et considéree à la lumière des réactions sérologiques. On trouva le facteur antinucléaire non-spécifique significativement plus souvent que le spécifique du granulocyte dans les sérums des patients malades depuis 5 ans ou plus, mais la différence n'était pas importante dans les sérums de ceux dont la maladie était plus courte.

Indépendamment de la durée de la maladie, les sérums contenant seulement le facteur antinucléaire spécifique du granulocyte accusaient peu de différence en ce qui concerne la spécificité des facteurs rhumatoïdes, mais les sérums contenant le facteur antinucléaire nonspécifique provenant des patients malades depuis plus longtemps accusaient de plus haut titres des facteurs rhumatoïdes réagissant avec la gamma-globuline hétérologue que les sérums de ceux dont la maladie était plus courte.

Ces résultats indiquent l'existence d'une corrélation étroite entre la spécificité des facteurs antinucléaires et celle des facteurs rhumatö̈des dans la polyarthrite rhumatoïde. Il semble aussi que la spécificité des facteurs antinucléaires est déterminée non seulement par la durée de la maladie mais aussi par sa gravité. específicos del organo queda contante a pesar de la aumentación de los títulos de los factores reumatoides.

$\mathrm{La}$ duración de la enfermedad fué conocida en 82 casos y considerada a la luz de los resultados serológicos. El factor antinuclear no específico fué encontrado con una frecuencia significativamente mayor que el específico del granulocito en los sueros de enfermos desde 5 años o más, pero la diferencia no fué importante en casos de enfermedad más corta.

Independientemente de la duración de la enfermedad, los sueros conteniendo sólo el factor antinuclear específico del granulocito acusaron pocas diferencias respecto a la especifidad de los factores reumatoides, pero los sueros conteniendo el factor antinuclear no específico de pacientes con enfermedad prolongada acusaron más altos títulos de los factores reumatoides reaccionando con la gammaglobulina heteróloga que los sueros de los pacientes enfermos durante un tiempo más corto.

Estos resultados indican la existencia de una correlación estrecha entre la especifidad de los factores antinucleares y la de los factores reumatoides en la poliartritis reumatoide. Parece también que la especifidad de los factores antinucleares se ve determinada no sólo por la duración de la enfermadad sino también por su severidad. 